Bangladesh Journal of Neuroscience 2015; Vol. 31 (1): 9-14

\title{
Association of Serum Uric Acid and Parkinson's Disease: A Case Control Study
}

\author{
MD. ENAYETUL ISLAM ${ }^{1}$, AMINUR RAHMAN ${ }^{2}$, FARHANA SALAM ${ }^{3}$, TAKIB UDDINAHMED ${ }^{4}$, UTTAM
} KUMAR SAHA ${ }^{5}$, ZAHED ALI ${ }^{4}$, SAKHAWAT HOSSAIN ${ }^{6}$, MD. RAFIQUL ISLAM $^{7}$

\begin{abstract}
:
Aim: Recent studies have provided evidence that uric acid (UA) is supposed to play a neuro-protective role in Parkinson's disease (PD). Uric acid is a natural antioxidant that may reduce oxidative stress, a mechanism thought to play a role in the pathogenesis of PD. This study aimed to evaluate whether the serum UA level was associated with $P D$ in a relatively small population of Bangladeshi patients.

Materials and methods: An observational prospective case control Study was conducted in Neurology department of Sir Salimullah Medical College \& Mitford Hospital including both the male and female wards during July 2012 to December 2013. Serum uric acid were determined from 40 PD patients and compared with 70 age and sex matched control; following the uric acid colorimetric method, the serum creatinine (Scr) levels were also measured to reduce the bias caused by possible differences in renal excretion function. Data were analyzed with software SPSS 16 and statistical descriptive methods (mean percentage, SD) and t-test. Result: In this study, 22 men (55\%) and 18 women (45\%) with PD were evaluated. The mean serum uric acid in patients was $3.7 \pm 0.97$ and in the control group was $5.32 \pm 0.44$. This difference was statistically significant. $(p=0.001) \mathrm{A} / \mathrm{so}$, the mean

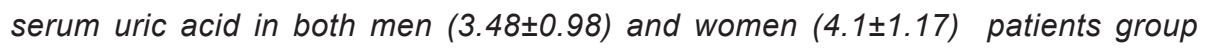

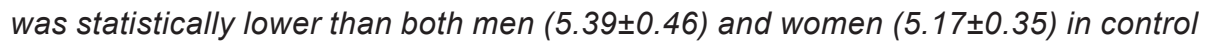
group. $(p=0.001)$. Conclusion: This present study showed a positive association between low serum UA and PD.
\end{abstract}

Key Word: Serum Uric Acid, Parkinson's disease

Abbreviation: Uric Acid(UA), Parkinson's disease(PD)

Introduction:

$\mathrm{PD}$ is the second commonest neurodegenerative disease, clinically characterized by rest tremor, rigidity, bradykinesia, and gait impairment and pathologically, there are degeneration of dopaminergic neurons in the substantia nigra pars compacta, reduced striatal dopamine, and intracytoplasmic proteinaceous inclusions known as Lewy bodies ${ }^{1}$.
UA is the final oxidation product of purine metabolism and is excreted in urine. It is a marker of oxidative stress, and may have a potential therapeutic role as an antioxidant 2,3 .

It is reported that uric acid could suppress oxidative stress and prevent dopaminergic cell death in animal models of Parkinson's disease. Reduced UA levels have been found not only in the substantia nigra but

1. Registrar, Department of Neurology, Sir Salimullah Medical College Mitford Hospital, Dhaka

2. Assistant Professor, Department of Interventional Neurology, National Institute of Neurosciences \& Hospital, Sher-E-Bangla Nagar, Dhaka.

3. Lecturer, Department of Anatomy, Sir Salimullah Medical College Mitford Hospital, Dhaka

4. Associate Professor, Department of Neurology, Sir Salimullah Medical College, Dhaka

5. Associate Professor, Department of Neurology, National Institute of Neurosciences \& Hospital, Dhaka.

6. Professor, Department of Neurology, Sir Salimullah Medical College, Dhaka.

7. Professor, Department of Neurology, Bangabandhu sheikh Mujib Medical University, Dhaka. 
also in the cerebrospinal fluid and serum of PD patients ${ }^{4,5,6}$

The association between UA and risk of PD has been investigated in several previous prospective studies and higher serum uric acid levels might have been correlated to a significantly reduced risk of $\mathrm{PD}^{7,8}$. There is also evidence that higher uric acid levels could slow the clinical progression of $P D^{9,10}$.

Some recent studies show that UA can decrease the onset of the disease or its intensity, because of having the antioxidant effects and this effect must be considered in the therapeutic process of the disease 11. Some other studies indicate that high uric acid levels lead to the decrease of the free radicals and subsequently the onset of the disease ${ }^{3}$.

Another 14 years period research in America revealed that the risk of onset of PD in people with higher dietary intake of uric acid index was much lower than others; instead, the onset of Gout and renal stones was higher than other people 7,12 . Some studies also show that the risk of PD is much lower in patients suffering from Gout ${ }^{13,14}$.

Despite the above researches, results of the recent researches are not yet adequate for a general conclusion. Yet there are many studies indicating the need for more investigations, 5,15,16,17.

Here, with considering the above studies, we would like to embark on measuring the serum UA levels in PD patients in Bangladesh to find out their association, so that the study result might open new era of future research regarding alternative management of PD.

\section{Materials and Methods:}

This is a observational prospective case control study, carried out on Parkinson patients in the Department of Neurology of Sir Salimullah Medical College \& Mitford Hospital, Dhaka Bangladesh from July 2012 to December 2013. Being manifested with the disease was confirmed through clinical examinations by a neurologist and the Para clinical measures according to Brain Bank clinical criteria for diagnosis of Parkinson's disease. All of the patients suffering from Gout, blood diseases and vasculitis, those who had a history of using the drugs effective on the uric acid levels (Corticosteroids, Colchicine, Alluporinol), and also the patients taking medications other than the anti - Parkinson drugs were excluded from the study. Then, 40 patients were included in the research. Meanwhile, 70 people of age and sex matched healthy individual from patient's attendants and yet had taken no specific medications were selected as the control group. The ethical committee of the Sir Salimullah Medical College, Dhaka, Bangladesh had approved the research. The serum uric acid levels were measured by milligram per deciliter, and the results were evaluated with $95 \%$ confidential interval. The values were registered with the demographic information of the questionnaire and were statistically analyzed by the use of the SPSS-16 software, the descriptive statistics methods (the number of percentage and average) and the analytic statistics (comparing the mean and the T- test and ANOVA).

\section{Results:}

In this study, the age distribution of study population in case group $15(37.5 \%)$ patients belonged to age $71-80$ years and their mean age was found $69.15 \pm 10.08$ years. In control group, $27(38.6 \%)$ patients belonged to 51-60 years and their mean age was $67.14 \pm 10.25$ years. The mean age difference was not statistically significant $(p>0.05)$ between two groups.(Table:I)

The observation of sex distribution of the study was, male $22(55.0 \%)$ and female $18(45.0 \%)$ in case group. The male were 40(57.1\%) and female were $30(42.9 \%)$ in control group. Male female ratio was found 1.22:1 \& 1.33:1 in case and control group respectively. The difference was not statistically significant $(p>0.05)$ between two groups.(Table:II)

In Table III shows serum uric acid of the study population. It was observed that mean serum uric acid was found $3.7 \pm 0.97 \mathrm{mg} / \mathrm{dl}$ in case group and $5.32 \pm 0.44 \mathrm{mg} / \mathrm{dl}$ in control group. The mean difference was statistically significant $(p<0.05)$ between two groups. 
Table-I

Distribution of the study population by age $(n=110)$

\begin{tabular}{|c|c|c|c|c|c|}
\hline \multirow[t]{2}{*}{ Age (in years) } & \multicolumn{2}{|c|}{ Case $(n=40)$} & \multicolumn{2}{|c|}{ Control $(n=70)$} & \multirow[t]{2}{*}{ Pvalue } \\
\hline & No & $\%$ & No & $\%$ & \\
\hline d"50 & 2 & 5.0 & 1 & 1.4 & \\
\hline $51-60$ & 8 & 20.0 & 27 & 38.6 & \\
\hline $61-70$ & 13 & 32.5 & 24 & 34.3 & \\
\hline $71-80$ & 15 & 37.5 & 9 & 12.9 & \\
\hline$>80$ & 2 & 5.0 & 9 & 12.9 & \\
\hline Mean $\pm S D$ & \multicolumn{2}{|c|}{$69.15 \pm 10.08$} & \multicolumn{2}{|c|}{$67.14 \pm 10.25$} & $0.321 \mathrm{~ns}$ \\
\hline Range (min, max) & \multicolumn{2}{|c|}{48,100} & \multicolumn{2}{|c|}{50,90} & \\
\hline
\end{tabular}

ns= not significant

$P$ value reached from unpaired t-test

Table-II

Distribution of the study population by sex $(n=110)$

\begin{tabular}{lllllll}
\hline Sex & \multicolumn{2}{c}{ Case $(n=40)$} & & \multicolumn{2}{c}{ Control $(n=70)$} & P value \\
\cline { 2 - 3 } \cline { 5 - 6 } & No & $\%$ & & No & $\%$ & \\
\hline Male & 22 & 55.0 & & 40 & 57.1 & $0.827 n s$ \\
Female & 18 & 45.0 & & 30 & 42.9 & \\
\hline
\end{tabular}

ns $=$ not significant

$P$ value reached from chi square test

Table-III

Distribution of the study population by serum uric acid $(n=110)$

\begin{tabular}{lcccccc}
\hline & \multicolumn{2}{c}{ Case $(\mathrm{n}=40)$} & & \multicolumn{2}{c}{ Control $(\mathrm{n}=70)$} & P value \\
\cline { 2 - 3 } \cline { 5 - 6 } & Mean & $\pm S \mathrm{SD}$ & & Mean & \pm SD & \\
\hline Serum uric acid $(\mathrm{mg} / \mathrm{dl})$ & 3.7 & \pm 0.97 & & 5.32 & \pm 0.44 & $0.001 \mathrm{~s}$ \\
Range (min,max) & 1.8 &, 5.8 & & 4.5 &, 6.2 & \\
\hline
\end{tabular}

$\mathrm{S}=$ significant

$P$ value reached from unpaired t-test

\section{Discussion:}

This observational prospective case control study was carried out with an aim to determine the relation of serum UA level with prevalence of PD and also to find out the correlation of UA with severity of PD.

In this study it was observed that in case group $37.5 \%$ patients were in 8 th decade and their mean age was $69.15 \pm 10.08$ years, varied $48-100$ years. In control, $38.6 \%$ patients were in 6 th decade and their mean age was $67.14 \pm 10.25$ years, varied 50 90 years. The mean age was almost alike between the two groups. In a recent research showed that the mean age of male patients of the control group was $64.7 \pm 6.4$ years and the mean age of the female patients of the control group was $63.2 \pm 5.6$ years ${ }^{18}$. There were no statistical differences between the mean ages of the estimated groups. $20 \%$ of patients were under $60,18 \%$ between $61-65,28 \%$ were between $66-70$ and $34 \%$ were more than 70 years old, which is consistent with the current study ${ }^{18}$. Another researcher mentioned in his study that one in seven patients with PD is under the age of 50 years, and there is an increase in prevalence with increasing age ${ }^{19}$. In this study only $5 \%$ of patients were 50 years or below which is much lower than that of previous study. The prevalence of PD in 
industrialized countries is thought to be approximately $0.3 \%^{20}$. This rises to $1.0 \%$ in people over the age of 60 and $3 \%$ in people over 80 years ${ }^{21}$. In the UK, PD is estimated to affect 100-180 per 100,000 of the population and has an annual incidence of 4-20 per 100,00022. Finding of present study regarding age also consistent with these previous studies.

In this study it was observed that male was $55.0 \%$ and $57.1 \%$ in case and control group respectively, which indicates that Parkinson's disease is more common in male subjects. Male to female ratio was 1.2:1 in case group and 1.3:1 in control group. The difference was not statistically significant $(p>0.05)$ between two groups. In a recent research showed, $52.0 \%$ of the people in both groups of case and control were males and $48.0 \%$ were females ${ }^{18}$. A similar previous study showed $53.8 \%$ were males and $46.2 \%$ were females ${ }^{23}$. Our present study supports previous studies.

In this present study it was observed that mean \pm SD serum uric acid was $3.7 \pm 0.97 \mathrm{mg} / \mathrm{dl}$ varied from 1.8 to $5.8 \mathrm{mg} / \mathrm{dl}$ in case group and $5.32 \pm 0.44 \mathrm{mg} / \mathrm{dl}$ varied from 4.5 to $6.2 \mathrm{mg} / \mathrm{dl}$ in control group. The mean serum uric acid level was significantly lower in case group $(p<0.05)$. Similarly, it was observed that the mean uric acid levels were $4.79 \pm 1.21 \mathrm{mg} / \mathrm{dl}$ in the patients group, and it was $5.85 \pm 1.14 \mathrm{mg} / \mathrm{dl}$ in the control group ${ }^{18}$. The serum uric acid levels in the case group was significantly lower than the control group $(p<0.001)$, which also consistent with the current study ${ }^{18}$. When compared male and female individually it was observed that serum uric acid was significantly lower in Parkinson's disease patients of both male and female separately. [ $3.48 \pm 0.98 \mathrm{mg} / \mathrm{dl}$ Vs $5.39 \pm 0.46 \mathrm{mg} / \mathrm{dl}(p<0.05)$ in male and $4.1 \pm 1.17 \mathrm{mg} / \mathrm{dl}$ Vs $5.17 \pm 0.35 \mathrm{mg} / \mathrm{dl}(\mathrm{p}<0.05)$ in female]. A recent study observed that the mean uric acid levels were significantly lower when compared male and female separately $(4.87 \pm 1.2$ $\mathrm{mg} / \mathrm{dl}$ and $4.70 \pm 1.23 \mathrm{mg} / \mathrm{dl}$ in male and female cases respectively Vs $5.42 \pm 1.25 \mathrm{mg} / \mathrm{dl}$ and $5.91 \pm$ $1.62 \mathrm{mg} / \mathrm{dl}$ in male and female controls respectively) which is supported by this study ${ }^{18}$.

Evaluation of serum uric acid level with disease severity observed that though it is not statistically significant; mean serum uric acid level was steadily lower with disease severity in stage II to IV but in stage $V$ there was a slight raise of serum uric acid level than that of stage IV. Schwarzschild et al. did a large prospective study among subjects in the early stages of PD enrolled in a randomized clinical trial and found that the rate of progression declined with increasing level of serum urate level ${ }^{10}$. Another study had observed among subjects with early PD participating in a large randomized trial, that both serum and CSF urate concentrations measured at baseline were inversely related to clinical progression of $\mathrm{PD}^{6}$. But a discriminating report was found in the study by Hau and Eugene, who observed that there was no significant correlation serum uric acid level and staging of PD except a trend of lower uric acid level in stage 5 patients ${ }^{24}$.

There was no relationship between the uric acid and the duration of illness (Table II), and this was in line with other studies. More researches still deem necessary in this area ${ }^{25-27}$. The main limitation of the research was the lack of comparison between the serum uric acid levels and the severity of illness which has to be considered in future studies ${ }^{28-30}$.

\section{Conclusion:}

This present study showed that the uric acid levels in the Parkinson's patients were lower than healthy people. This means that the decrease of the uric acid levels lead to more outbreak of Parkinson both in men and women. This finding confirms the previous studies, emphasizes on the role of uric acid levels on the PD, and also indicates the necessity of more studies specially the cohort studies to achieve a final result and to clarify a part of the treatment process.

\section{Acknowledgements:}

This article is the outcome of MD (Neurology) thesis Dr. Md Enayatul Islam under university of Dhaka, Bangladesh..

\section{Authors' Contributions:}

All authors had equal role in design, work, statistical analysis and manuscript writing.

\section{Conflict of Interest:}

The authors declare no conflict of interest. 


\section{References:}

1. Longlo, DL, Kasper, DL, Jameson, IJ, Fauci, AS, Mauser, SL \& Loscalzo, J 2012, 'Harrison's principles of internal medicine', $18^{\text {th }}$ ed. New York McGraw Hill. pp. 3317-35.

2. Becker, BF 1993, 'Towards the physiological function of uric acid', Free Radical Biology \& Medicine.1993;14(6): 615-31.

3. Glantzounis, GK, Tsimoyiannis ,EC, Kappas, AM \& Galaris, DA.'Uric acid and oxidative stress', Curr Pharm Des,200511(32):4145-51.

4. Church, WH \& Ward, VL.'Uric acid is reduced in the substantia nigra in Parkinson's disease: effect on dopamine oxidation', Brain Res Bull, 1994;33:419-25.

5. Davis, JW, Grandinetti, A, Waslien, Cl, Ross, GW, White, LR \& Morens, DM 1996, 'Observations on serum uric acid levels and the risk of idiopathic Parkinson's disease', $A m$ J Epidemiol, vol. 144, no. 5, pp. 480-84.

6. Ascherio, A, LeWitt, PA, Xu, K, Eberly, S, Watts, A \& Matson, WR et al. 'Urate as a predictor of the rate of clinical decline in Parkinson disease', Arch Neurol, 2009; 66(12), 1460-68.

7. Gao, X, Chen, H, Choi, HK, Curhan, G, Schwarzschild, MA \& Ascherio, A. 'Diet, urate and Parkinson's disease risk in men', $A m \mathrm{~J}$ Epidemiol. 2008;167(7): 831-38.

8. de Lau, LM, Koudstaal, PJ, Hofman, A \& Breteler, MM. 'Serum uric acid levels and the risk of Parkinson disease', Ann Neurol, 2005; 58: 797-800.

9. Schiess, M \& Oh, I. 'Serum uric acid and clinical progression in Parkinson disease: potential biomarker for nigrostriatal failure', Arch Neurol, 2008 (65,)698-99.

10. Schwarzschild, MA, Schwid, SR, Marek, K, Watts, A, Lang, AE \& Oakes, D et al. 'Serum urate as a predictor of clinical and radiographic progression in Parkinson disease', Arch Neurol,2008; 65: 716-23.

11. Andreadou, E, Nikolaou, C \& Gournaras, F. 'Serum uric acid levels in patients with
Parkinson's disease: Their relationship to treatment and disease duration', Clin Neurol Neurosurg,2009; 111(9,) 724-8.

12. de Lau, LM, Koudstaal, PJ \& Hofman, A.'Serum uric acid levels and the risk in men', Am J Epidemiol, 2008; 167: ( 7) 831-8.

13. De Vera, M, Rahman, MM \& Rankin, J. ‘Gout and risk of Parkinson's disease: A cohort study', Arthritis Rheum, 2008; 59(11): 1549-54.

14. Schlesinger, I \& Schlesinger, $N$.'Uric acid in Parkinson's disease', Mov Disord, 2008; 23(12):16.

15. Prasad, KN, Cole, WC \& Kumar, B 1999, 'Multiple antioxidants in the prevention and treatment of Parkinson's disease', J Am Coll Nutr, vol. 18, no. 5, pp. 413-23.

16. Frasier, M, Chowdhury, S, Eberling, J \& Sherer, T 2010, 'Biomarkers in Parkinson's disease: A funder's perspective', Biomark Med vol. 4, no. 5, pp. 723-9.

17. Tanner, CM. 'Advances in environmental epidemiology', Mov Disord.2010;25 (S1): S58-62.

18. Iranmanesh, F, Gadri, F, Bakhshi, H \& Sarhadi, S. 'Serum Uric Acid Level in Patients with Parkinson Disease', Zahedan Journal of Research in Medical Sciences.2010;1-3

19. Findley, LJ. 'The economic impact of Parkinson's disease', Parkinsonism Relat. Disord. 2007;13: S8-S12.

20. de Lau, LM \& Breteler, MM.'Epidemiology of Parkinson's disease', Lancet Neurol, vol. 5, no. 6, pp. 525-35.

21. Nussbaum, RL \& Ellis, CE.'Alzheimer's disease and Parkinson's disease', $N$ Engl $J$ Med,2003;348( 14):1356-64.

22. The National Collaborating Centre for Chronic Conditions (2006). Parkinson's disease: national clinical guideline for diagnosis and management in primary and secondary care. London: Royal College of Physicians.

23. Tan, LCS, Tan, AKY \& Tjia, HT.'The Profile of Hospitalised Patients with Parkinson's Disease', Ann Acad Med Singapore, 1998; 27:808-12. 
24. Hau,JG, Eugene C 'Correlation of serum uric acid levels with Parkinson's Disease symptom severity', Parkinson's Disease research education and clinical centre.

25. Annanmaki T, Muuronen A, Murros K. Low plasma uric acid level in Parkinson's disease. Mov Disord 2007; 22(8): 1133-7.

26. Schlesinger I, Schlesinger N. Uric acid in Parkinson's disease. Mov Disord 2008; 23(12): 16.

27. Shoulson I, Lasagna LC. Therapeutic directions for Parkinson's Disease. Mov Disord 2010; 25(Suppl 1): S152-S154.
28. Weisskopf MG, O'Reilly E, Chen H, et al. Plasma urate and risk of Parkinson's disease. Am J Epidemiol 2007; 166(5): 561-7.

29. Chen H, Mosley TH, Alonso A, et al. Plasma urate and Parkinson's disease in the Atherosclerosis Risk in Communities (ARIC) study. Am J Epidemiol 2009; 169(9): 10641069.

30. Winquist A, Steenland K, Shankar A. Higher serum uric acid associated with decreased Parkinson's disease prevalence in a large community-based survey. Mov Disord 2010; 25(7): 932-936. 